\title{
Growth Rate and Sexual Maturity in Cod (Gadus morhua) and Atlantic Halibut (Hippoglossus hippoglossus)
}

\author{
O. R. Godø \\ Institute of Marine Research, P. O. Box 1870 Nordnes \\ N-5817 Bergen, Norway \\ and \\ T. Haug \\ Norwegian Institute of Fisheries and Aquaculture \\ N-9291 Troms $\varnothing$, Norway
}

\begin{abstract}
Variation in growth and reproduction dynamics of fish populations substantially affects production in wild as well as domesticated fish populations. Identifying the intrinsic and environmental factors which influence the dynamics of these traits is important for stock assessment methodology and management of wild fish populations as well as for improving production in aquaculture.

In this paper the relationship between growth and maturation of cod (Gadus morhua) and Atlantic halibut (Hippoglossus hippoglossus) is described using data from spawning locations along the Norwegian coast. Both species show an inverse relationship between immature growth and age/size at first spawning. Long term trends may be connected to climatic changes as well as to the increased exploitation experienced in this century. Shortterm variation may be caused by abrupt changes in the conditions for growth, e.g. due to temperature shifts and/or variation in prey abundance.
\end{abstract}

Key words: Atlantic halibut, cod, growth, maturity, Norway

\section{Introduction}

Traditionally, cod (Gadus morhua) and Atlantic halibut (Hippoglossus hippoglossus) are important commercially exploited species in Norway. Overexploitation of wild stocks and recent advancements in marine aquaculture have made domestication more viable (Haug, 1990; Tilseth, 1993). The age/size at onset of maturation and growth rate are important stock parameters required for reliable assessment and prediction of commercially exploited fish species. These parameters are also of crucial importance in aquaculture and set the limits on the commercial potential of the species.

The scientific literature has not reached a consensus over whether organisms mature at a fixed age or at a fixed size. According to Stearns and Crandall (1984) they probably do neither, in that selection seems to operate on the shape of age/size maturation trajectories. Over some portions of these trajectories, organisms mature at a fixed size. Over other portions, organisms mature at a fixed age. In a study of several flatfish species, Roff (1982) suggested that age could be more important than size for early maturing species and vice versa for late maturing species. According to Stearns and Crandall (1984) it is only by considering maturation events occurring across a wide range of growth rates that one can perceive the shape of the whole trajectories.

Growth rates of fish are density-dependent, and vary with factors such as temperature, food availability and exploitation (see Beverton and Holt, 1959; Bromley, 1989). The heavily exploited stocks of northeast Arctic cod and Atlantic halibut in Norwegian waters have exhibited considerable variation in growth this century. Jørgensen (1990) demonstrated a considerable decrease in both the age and size at onset of maturation which occurred simultaneously with increased fishing pressure. Reduced age at maturity following overexploitation 
is even more pronounced for the halibut (Haug and Tjelmsland, 1986). In this species considerable reductions in male length at maturity have been observed between two time periods (Jakupsstovu and Haug, 1988). These results may suggest a of relationship between growth rate and sexual maturity for these species. Accumulation of age and size information from different periods with varying stock abundance permits analysis of this relationship, and is the main objective of this paper.

Fish need extra energy to be able to start the maturation process. The energy has to be obtained by predation or by using accumulated energy stored in body tissue (Love, 1970). It is thus hypothesised that the onset of maturation is initiated when the fish accumulate enough energy per unit of time and/or have enough reserves of energy in the body tissue to be able to fulfil maturation and spawning in the coming season, i.e. at a satisfactory maturation condition.

\section{Materials and Methods}

Coastal cod and northeast Arctic cod are caught together on the same spawning grounds in Norwegian waters but are considered two management units. In this paper coastal cod and northeast Arctic cod taken from three major spawning areas off the Norwegian coast in 1983 (Møre, Lofoten and Vesterålen, see Fig. 1, Table 1) are studied. The two types of cod are distinguished from differences in the otolith zonation (Rollefsen, 1933). Data from all major fishing gears are pooled under the assumption that this minimises the effect of gear selectivity. Only data from March and April (the main spawning season, see Pedersen, 1984) have been used. Comparison with data from a time series (1932-87) has become possible through

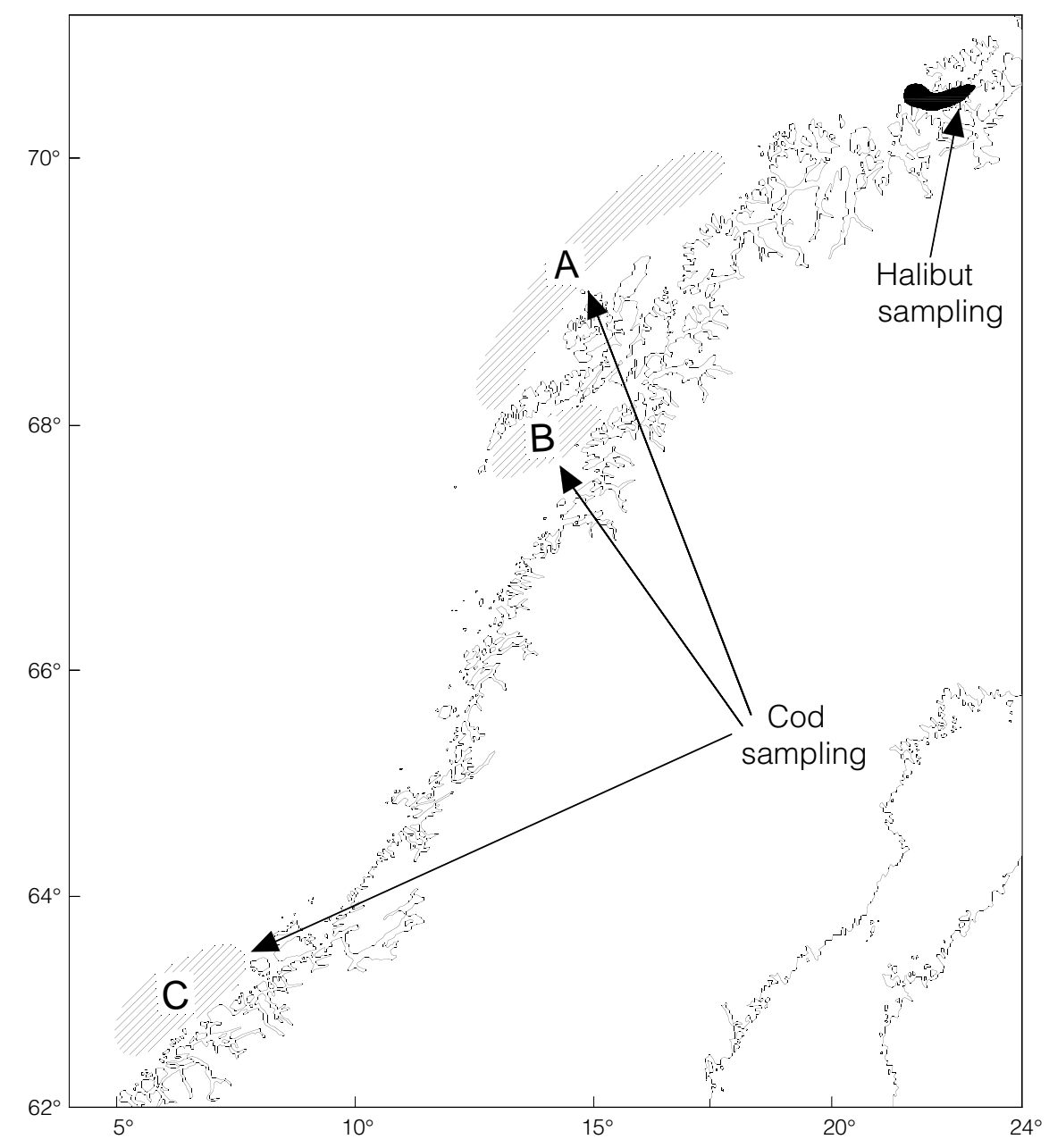

Fig. 1. Sampling areas for cod and halibut $(\mathbf{A}=$ Vesterålen, $\mathbf{B}=$ Lofoten, $\mathbf{C}=$ Møre $)$. 
TABLE 1. The Atlantic cod data from the Norwegian coast in 1983. $\mathrm{N}$ is sample size, $\mathrm{L}$ is mean length and SD standard deviation of the length at maturity. Area A, B and C according to Fig. 1. Type CC is coastal cod, AC is northeast Arctic cod.

\begin{tabular}{|c|c|c|c|c|c|c|c|c|c|c|}
\hline Type & Area & & 3 & 4 & 5 & 6 & 7 & 8 & 9 & 10 \\
\hline \multirow[t]{3}{*}{$\mathrm{CC}$} & A & $\mathrm{N}$ & & 12 & 80 & 59 & 21 & 8 & & \\
\hline & & $\mathrm{L}$ & & 55.2 & 66.9 & 68.3 & 81.7 & 88.8 & & \\
\hline & & SD & & 4.8 & 5.5 & 5.7 & 6.9 & 9.9 & & \\
\hline \multirow[t]{3}{*}{$\mathrm{CC}$} & B & $\mathrm{N}$ & & & 26 & 73 & 37 & 15 & & \\
\hline & & $\mathrm{L}$ & & & 63.9 & 68.7 & 79.0 & 91.6 & & \\
\hline & & SD & & & 6.6 & 5.3 & 9.5 & 12.4 & & \\
\hline \multirow[t]{3}{*}{$\mathrm{CC}$} & $\mathrm{C}$ & $\mathrm{N}$ & 19 & 23 & 61 & 14 & & & & \\
\hline & & $\mathrm{L}$ & 45.6 & 65.1 & 69.9 & 68.8 & & & & \\
\hline & & SD & 7.6 & 7.2 & 7.6 & 6.8 & & & & \\
\hline \multirow[t]{3}{*}{$\mathrm{AC}$} & A & $\mathrm{N}$ & & & 15 & 116 & 332 & 497 & 66 & 5 \\
\hline & & $\mathrm{L}$ & & & 61.1 & 67.2 & 73.4 & 83.1 & 94.6 & 105.2 \\
\hline & & SD & & & 4.1 & 4.2 & 5.0 & 6.8 & 6.2 & 7.2 \\
\hline \multirow[t]{3}{*}{$\mathrm{AC}$} & B & $\mathrm{N}$ & & & 3 & 223 & 809 & 890 & 122 & 6 \\
\hline & & $\mathrm{L}$ & & & 58.7 & 67.8 & 74.8 & 84.6 & 94.8 & 104.5 \\
\hline & & SD & & & 1.5 & 3.9 & 5.3 & 11.7 & 6.3 & 3.9 \\
\hline \multirow[t]{3}{*}{$\mathrm{AC}$} & $\mathrm{C}$ & $\mathrm{N}$ & & & & 15 & 182 & 211 & 67 & 23 \\
\hline & & $\mathrm{L}$ & & & & 66.3 & 78.2 & 84.6 & 92.5 & 103.2 \\
\hline & & SD & & & & 3.5 & 25.5 & 19.9 & 4.8 & 4.8 \\
\hline
\end{tabular}

TABLE 2. The Atlantic halibut data from the Norwegian coast in 1957 and $1981-86 . \mathrm{N}$ is sample size, L is mean length and SD standard deviation of the length at maturity.

\begin{tabular}{llcccccccrccc}
\hline \hline Year & & 5 & 6 & 7 & 8 & 9 & 10 & 11 & 12 & 13 & 14 & 15 \\
\hline 1957 & $\mathrm{~N}$ & & & & & 5 & 6 & 10 & 11 & 19 & 6 & 7 \\
& $\mathrm{~L}$ & & & & & 82.8 & 96.8 & 101.6 & 112.5 & 119.8 & 117.3 & 121.4 \\
& $\mathrm{SD}$ & & & & & 13.3 & 10.4 & 8.6 & 6.0 & 11.5 & 11.1 & 8.8 \\
1981 & $\mathrm{~N}$ & 5 & 25 & 20 & 36 & 10 & & & & \\
1986 & $\mathrm{~L}$ & 76.2 & 79.3 & 84.7 & 86.9 & 92.8 & & & & \\
& $\mathrm{SD}$ & 6.4 & 15.9 & 19.3 & 15.9 & 17.7 & & & & & \\
\hline
\end{tabular}

utilization of the same database as applied by Jørgensen (1990, 1992). These data were random samples from long line catches taken on the Lofoten spawning grounds during the spawning season. Males and females are pooled.

Atlantic halibut from one spawning area off North Norway (Sørøysundet, see Fig. 1) is studied based on samples from research gill net spawning fishery (January-February) in 1957 and 1981-86, using gill nets of various mesh sizes $(9,16,18,19$ and 23 inches, see Haug and Tjemsland, 1986) (Table $2)$. Data from all nets were pooled, in order to minimise the effect of selectivity of the various mesh sizes. Females are scarce in gillnet catches during the spawning season, and therefore data from males only are analysed here.

For both the above species total length was measured and sagittal otoliths were sampled for age determination. Rollefsen (1933) observed that the character of the most recent annual rings in cod otolith varied among mature individuals at the spawning grounds. The larger and older individuals exhibited an increasing number of narrow and distinct zones. Corresponding to this change in the otoliths, the growth of the cod was reduced, and Rollefsen (1933) interpreted these changes as a result of maturation. Devold (1938), although not so pronounced as for cod, observed similar changes, in 
halibut otoliths. In the present paper, changes in otolith structure were used as a criterion for determination of age at sexual maturity in both cod and halibut. The studied fish were caught during the spawning season, and all fish with running or maturing gonads but without narrow otolith zones were considered first time spawners. Fish with one or several narrow otolith zones were interpreted as multiple spawners and omitted from the analysis. Jørgensen (1990) who utilised the same material in his analysis discusses the validity of using zonation in cod otoliths to distinguish first spawners from multiple spawners.

Length at first spawning divided by age is used as an index of immature growth for both species.

\section{Results}

\begin{abstract}
Atlantic cod
The age and length span at which coastal cod matured in 1983 (3-8 years and 45-91 cm), was generally lower than for northeast Arctic cod (5-10 years and 58-105 cm) (Fig. 2a). Both the 1983 data and the time series 1932-87 show that length at maturation increase with increasing age (Fig. 2a-3a). The observation from the time series tend to show lower values for the oldest fish, and do also include data up to age 14 compared to age 10 in 1983. Standard deviations from the 1983 data and the spread of the time series points indicate considerable variability (Table 1, Fig. 3).
\end{abstract}
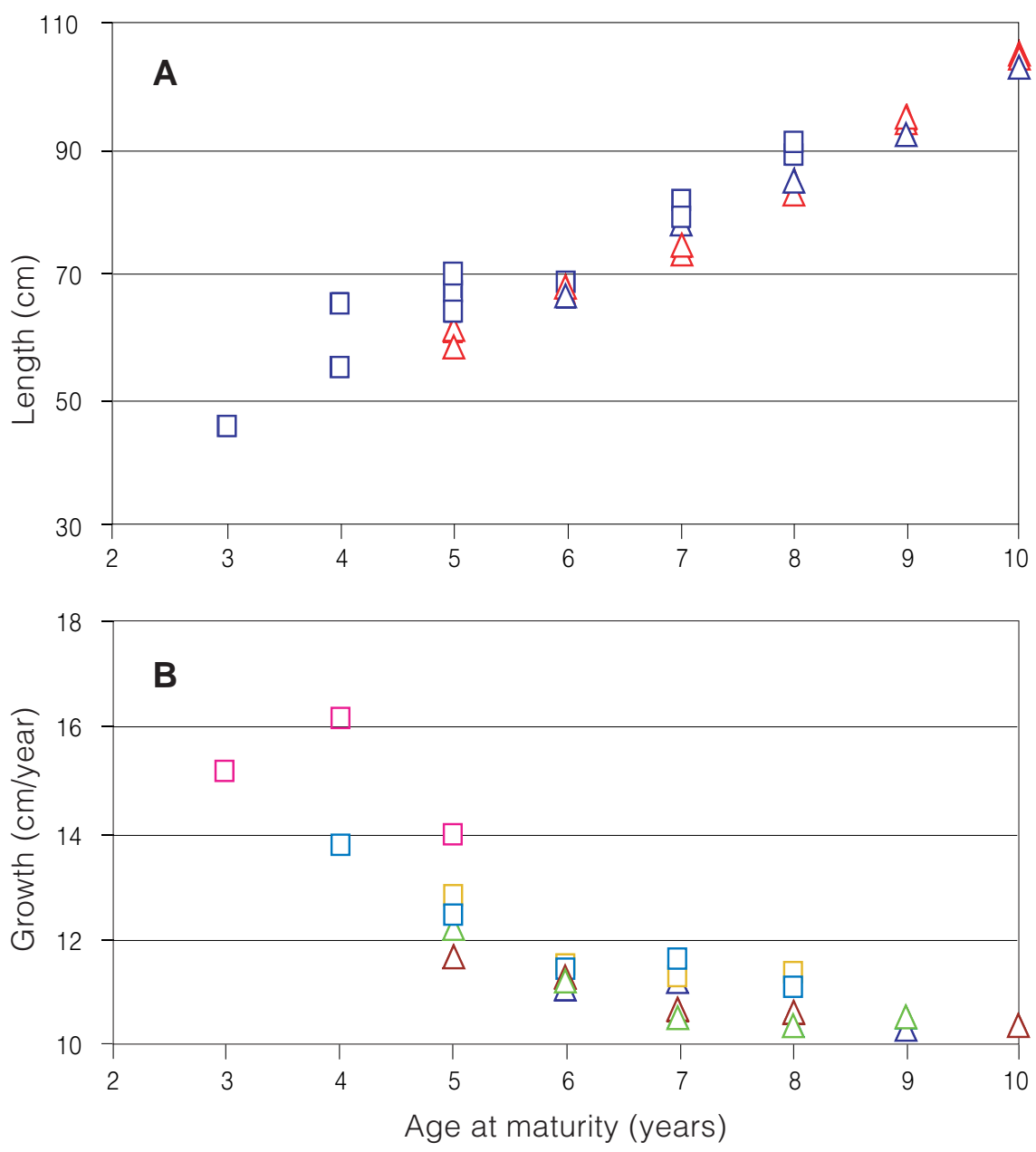

Fig. 2 The relationships between A) length and age at maturity, and B) growth rates and age at maturity as observed from data in 1983 for coastal cod (squares) and Northeast Arctic cod (triangles). 

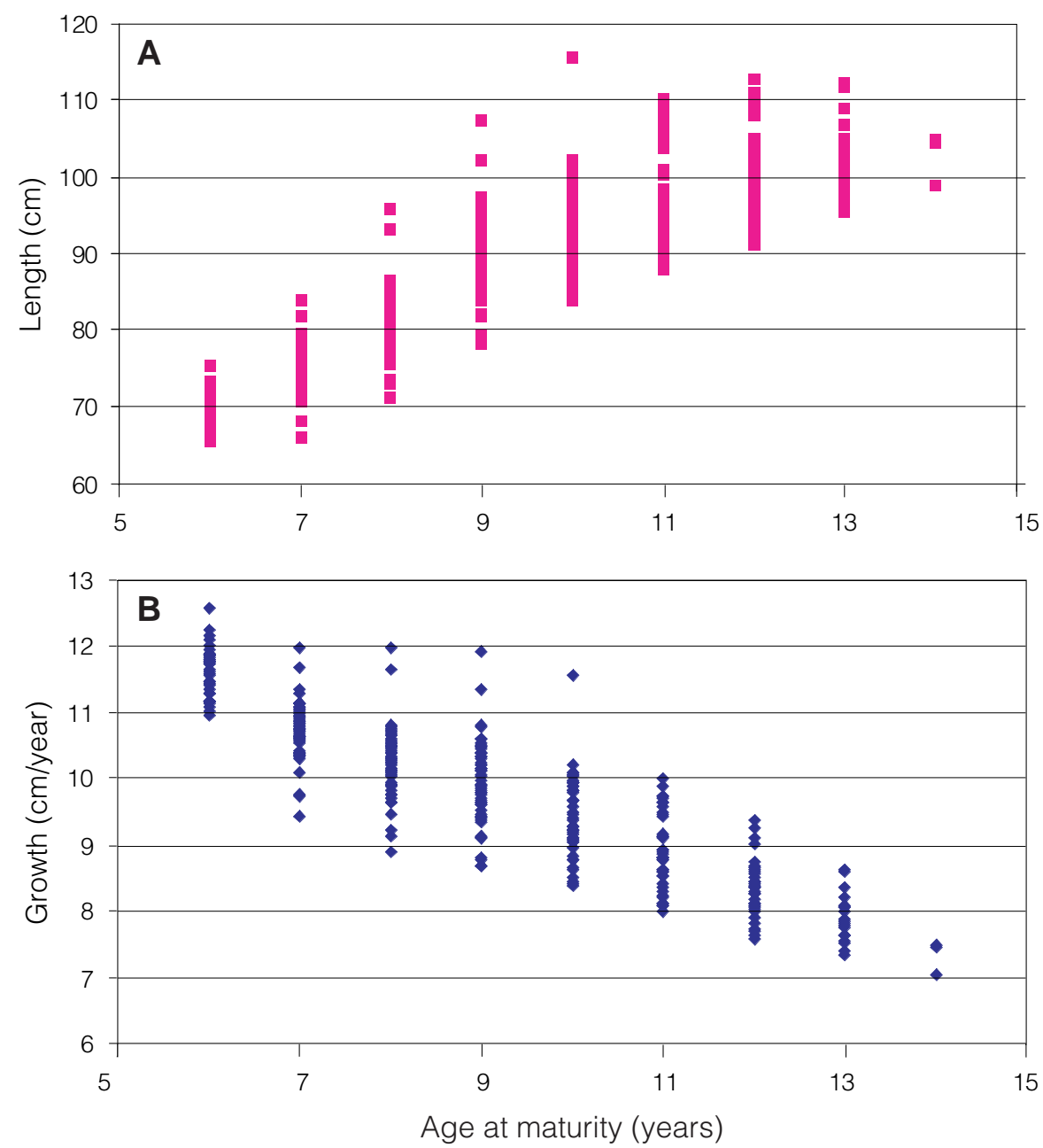

Fig. 3. The relationships between A) length and age at maturity, and B) growth rates and age at maturity as observed for Northeast Arctic cod from the time series 1932-87.

The immature growth calculations indicate an inverse relationship with age at maturation (Fig. 2b and $3 \mathrm{~b}$ ). The time series indicate slower average growth for the older fish.

Over the six decades of data there has been no change in minimum age at maturity whereas maximum age at maturity has been reduced from 14 to 10 (Table 3). No specific trend appears in mean, maximum and minimum lengths at maturity although they all peaked during the 1950s and 1960s.

\section{Atlantic halibut}

There is a considerable difference in age and length span at maturation of Atlantic halibut from the two investigated periods, i.e. male halibut matured in 1957 at age 9 to 15 years while in the
1980 s at age 5 to 10 years (Fig. 4a). The inverse relationship between immature growth and age at maturation observed for cod is also demonstrated for halibut (Fig. 4b).

\section{Discussion}

\section{Growth/maturity relationship}

Previous studies have demonstrated simultaneous changes in growth and age at maturation for both northeast Arctic cod (Hylen and Nakken, MS 1985; Jørgensen, 1990, 1992; Anon., MS 1989) and Atlantic halibut (Haug and Tjemsland, 1986), and may thus indicate some kind of relationship between these parameters. The present results demonstrate that maturation of cod and halibut do not occur at fixed/critical sizes or ages and thus support the 
TABLE 3. Decadal changes in mean length with standard deviation (SD length), and minimum and maximum age (mina maxa) and length (minl maxl) at maturity of cod.

\begin{tabular}{lcccccc}
\hline \hline Decade & Mean length & SD length & Mina & Maxa & Minl & Maxl \\
\hline 30 & 88.9 & 9.9 & 6 & 14 & 67.8 & 104.8 \\
40 & 86.2 & 9.6 & 7 & 13 & 66.1 & 106.8 \\
50 & 88.6 & 12.3 & 6 & 13 & 66.5 & 112.3 \\
60 & 89.8 & 12.7 & 6 & 13 & 69.5 & 112.7 \\
70 & 85.5 & 12.3 & 6 & 11 & 66.8 & 108.7 \\
80 & 83.9 & 11.9 & 6 & 10 & 65.7 & 107.4 \\
\hline
\end{tabular}
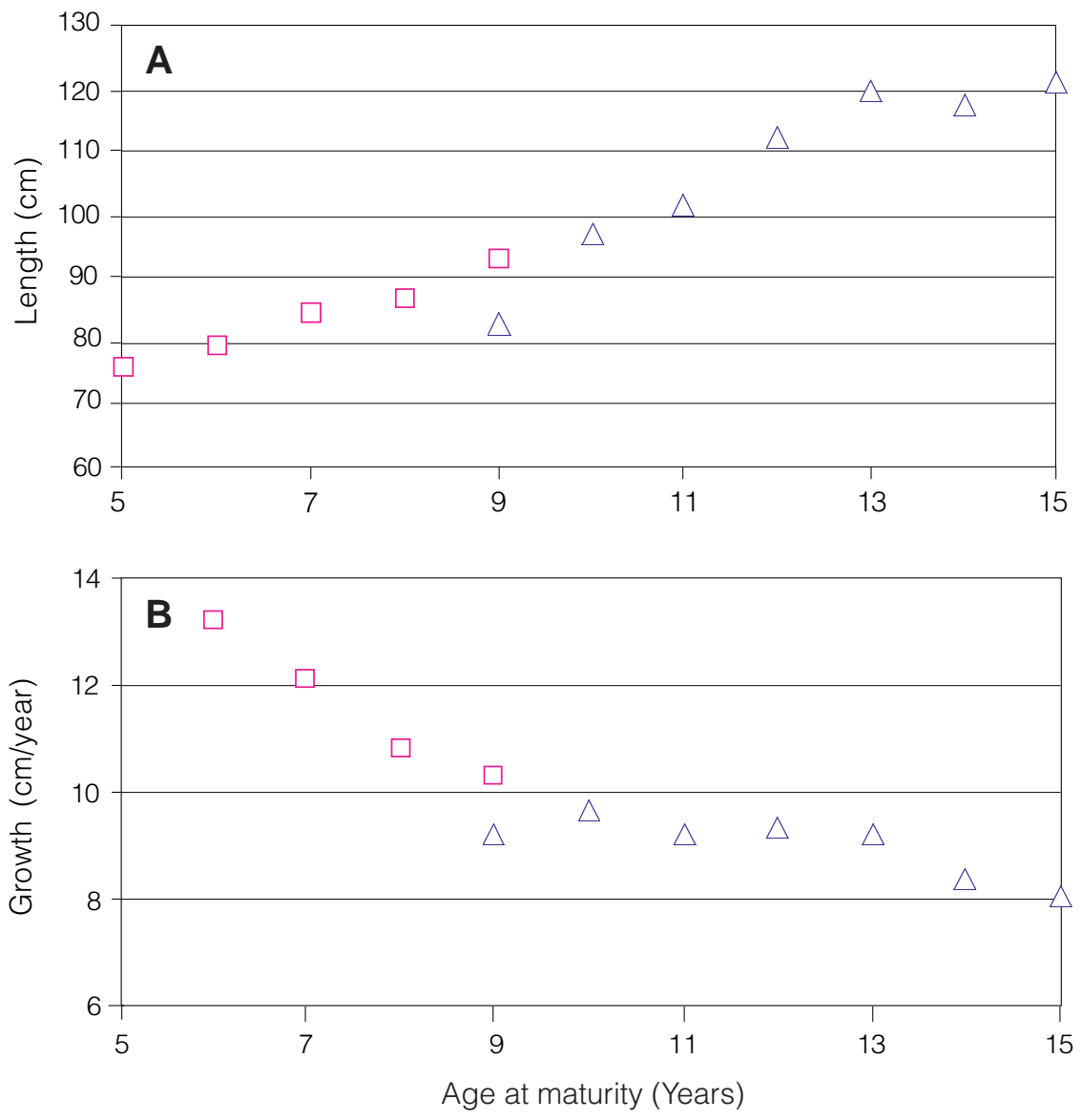

Fig. 4. The relationships between $\mathbf{A}$ ) length and age at maturity, and $\mathbf{B}$ ) growth rates and age at maturity for halibut as observed from data in 1957 (triangles) and in the 1980s (squares).

suggestions of Stearns and Crandall (1984). Our data show an inverse relationship between age/size at maturation and immature growth of both species. Thus, rapidly growing individuals, which attain maturity at the lower ages, will mature at shorter average lengths than the more slow-growing and latematuring individuals.
For both species, growth seems to approach an asymptotic value with increasing age at maturation. Possibly there is an age at which a species will always have the potential for reaching sexual maturity. In this case the outcome (maturation/no maturation) will be determined by the condition for growth in the season prior to spawning. The 
philosophy behind all fish aquaculture is to produce as many fish as possible in the shortest possible time. Increased growth rate is therefore desirable. The results presented here reveal that an increased growth rate in cod and halibut most probably will be accompanied by a subsequent decrease in age and size at sexual maturity. Since it is not economically feasible to rear the species beyond sexual maturity, the prospect of reduced size at maturity following increased growth may particularly indicate the necessity of selective breeding experiments in order to increase the aquaculture potential of both species.

\section{Methodological problems}

The present analysis depends totally on the validity of using zonation in the otoliths to distinguish first time spawners from multiple spawners. Jørgensen (1990), from whom we got our historic material, emphasize the consistency of material. Few and very experienced readers have been used for the whole period, and if the readings are biased, trends should be pertinent.

The discrepancy between the two sets of cod data is partly because coastal cod is included in the 1983 data. Furthermore the time trend in the data of northeast Arctic cod, described by Jørgensen (1990, 1992), influence the relationship. For these data the selective properties of long lines will favour the smaller individuals of the oldest fish. The basis for including coastal cod in the 1983 data set can be questioned. Coastal cod and northeast Arctic cod have very different age and size at maturation, but a possible genetic difference is disputed (Møller, 1968, 1969; Mork, 1985; Mork et al., 1985; Fevolden and Pogson, 1998). In this paper, however, we want to illustrate the more general relationship between growth and maturation, which is not necessarily dependent of the stock identity/management unit question. By extrapolating towards lower age in Fig. $2 \mathrm{~b}$, it is indicated that a growth rate of about $20 \mathrm{~cm}$ per year is necessary to obtain maturation at age 2 . This is reasonably close to what has been observed in laboratory studies (Godø and Moksness, 1987).

Unfortunately the halibut material did not include females in sufficient numbers to complete the analyses of this species. Available data on female halibut indicate that maturation occurs at similar average sizes $(110-120 \mathrm{~cm})$ independent of area and time period (McCracken, 1958; Rae, 1959; Bowering, 1986; Jakupsstovu and Haug, 1988). A sex differentiation may thus be indicated. However, with the problems involved in sampling females representatively, no firm conclusion can be drawn.

\section{Possible ecological implication}

Considerable individual variation in growth of immatures is known to occur for cod (Jørgensen, 1992) and halibut (Jespersen, 1917). The relatively high variability in the results (Table 1 and Fig. 2-4) is therefore not unexpected. Furthermore, from laboratory studies it is indicated that growth and age at maturation in cod respond quickly to improved rearing conditions by increased growth and a reduced age at maturation (Godø and Moksness, 1987). Laboratory experiments also show that immature Atlantic halibut, when given sufficient food, may increase their annual growth rate substantially (Haug et al., 1989). The investigated cod and halibut stocks, which naturally occur over vast areas off the Norwegian coasts (Bergstad et al., 1987, Haug, 1990), spend their immature life under variable growing conditions (Loeng, 1989). The distribution and growth of immature cod is dependent on temperature distribution and the location and movements of fronts between water masses (Nakken and Raknes, 1987). Along with environmental changes, food availability may also shift rapidly (Mehl and Sunnanå, 1991). Combined, these factors may certainly influence growth and thus the maturation conditions for cod as well as for halibut. This could be an important causal factor for shortterm variation in age/size at maturation.

Having seen that changes in growth rate most probably will cause changes in age and size at maturity, is it possible to find reasonable explanations to the observed long-term changes in age at maturity? A heavy exploitation pressure will reduce the probability of fish to reach a high age and hence to mature late. Further, the northern and eastern nursery grounds of the Barents Sea/Svalbard region are the areas with the coldest waters and slowest growth. Atlantic halibut inhabited some of these oceanic grounds before stock depletion (Haug, 1990). Since 1981 juveniles have been absent here (Norwegian groundfish surveys unpubl. results). Similarly for cod, the proportion of spawners from the northern and eastern oceanic nursery areas may have been reduced in the mature population as a result of the strong increase of trawling in these areas after World War II (Sætersdal and Hylen, 1964, Bergstad et al., 1987). This is also the period with the most notable decrease in age at first spawning (Table 3, Jørgensen, 1990). It is thus plausible that 
the main recruitment to the investigated spawning areas, particularly for halibut, in the 1980s to a greater extent came from the more southern and warmer parts of the nursery areas compared to earlier. In recent decades both these stocks have been reduced (Bergstad et al., 1987; Haug, 1990) simultaneously with other presumed competitors like haddock (Melanogrammus aeglefinus) (Bergstad et al., 1987) and Greenland halibut (Reinhardtius hippoglossoides) (Godø and Haug, 1989). This may have reduced both intra- and inter-specific competition. In combination, these factors may have improved living condition for both species and thus reduced the time necessary for accumulating enough energy to start the maturation process. Densitydependent reactions have also been observed in other Barents Sea top predators, e.g. in harp seals (Phoca groen-landica) when simultaneous population increase and prey depletion were accompanied by declined individual growth and increased age at maturity from the mid-1960s to the early-1990s (Kjellquist et al., 1995).

\section{Acknowledgements}

We are grateful to T. Jørgensen, Institute of Marine Research, who gave us access to his detailed historic data on cod. Valuable comments and suggestions to this manuscript from T. Marshall, Institute of Marine Research and O. T. Albert, Norwegian Institute of Fisheries and Aquaculture were much appreciated.

\section{References}

ANON. MS 1989. Report of the Arctic Fisheries Working Group. Copenhagen, 20-29 September 1988. ICES C. M. Doc., No. Assess:4, 171 p.

BERGSTAD, O. A., T. JØRGENSEN, and O. DRAGESUND. 1987. Life history and ecology of the gadoid resources of the Barents Sea. Fish. Res., 5: 119-161.

BEVERTON, R. J. H., and S. J. HOLT. 1959. A review of the life-spans and mortality rates of fish in nature, and their relation to growth and other physiological characteristics. CIBA Found., Colloq. Ageing, 5: 147177.

BOWERING, W. R. 1986. The distribution, age and growth and sexual maturity of Atlantic halibut (Hippoglossus hippoglossus) in Newfoundland and Labrador area of Northwest Atlantic. Can. Tech. Rep. Fish. Aquat. Sci., 1432: iv+34p.

BROMLEY, P. J. 1989. Evidence for density-dependent growth in North Sea gadoids. J. Fish Biol., 35: 117123.
DEVOLD, F. 1938. The North Atlantic halibut and net fishing. FiskDir. Skr. Ser. HavUnders., 5(6): 1-47.

FEVOLDEN, S. E., and G. H. POGSON. 1998. Genetic divergence at the synaptophysin (Syp I) locus among Norwegian coastal and north-east Arctic populations of Atlantic cod. J. Fish Biol., 51: 895-908.

GODØ, O. R., and T. HAUG. 1989. A review of the natural history, fisheries, and management of Greenland halibut (Reinhardtius hippoglossoides) in the eastern Norwegian and Barents Sea. ICES J. Cons., 46: 6275.

GODØ, O. R., and E. MOKSNESS. 1987. Growth and Maturation of Norwegian Coastal Cod and Northeast Arctic Cod under Different Conditions. Fish. Res., 5: 235-242.

HAUG, T. 1990. Biology of the Atlantic halibut (Hippoglossus hippoglossus L., 1758.) Adv. Mar. Biol., 26: 1-70.

HAUG, T., I. HUSE, E. KJØRSVIK, and H. RABBEN. 1989. Observations on the growth of juvenile Atlantic halibut (Hippoglossus hippoglossus L.) in captivity. Aquaculture, 80: 77-86.

HAUG, T., and J. TJEMSLAND. 1986. Changes in sizeand age-distributions and age at sexual maturity in Atlantic halibut, Hippoglossus hippoglossus, caught in North Norwegian waters. Fish. Res., 4: 145-155.

HYLEN, A., and O. NAKKEN. MS 1985. Stock size of north-east Arctic cod, estimates from survey data 1984/1985. ICES C.M. Doc., No. G:67: 14 p.

JAKUPSSTOVU, S. H., and T. HAUG. 1988. Growth, sexual maturation, and spawning season of Atlantic halibut, Hippoglossus hippoglossus, in Faroese waters. Fish. Res., 6: 201-215.

JESPERSEN, P. 1917. Contribution to the life history of the North Atlantic halibut (Hippoglossus hippoglossus Flem.). Medd. Dan. Fisk.-Havunders., N. S., 5(5):132.

JØRGENSEN, T. 1990. Long-term changes in age at sexual maturity of Northeast Arctic cod (Gadus morhua L.). ICES J. Cons., 46: 235-248.

JØRGENSEN, T. 1992. Long-term changes in growth of North-East Arctic cod (Gadus morhua) and some environmental influences. ICES J. Mar. Sci., 49: 263-277.

KJELLQUIST, S. A., T. HAUG, and T. ØRITSLAND. 1995. Trends in age-compositions, growth and reproduction parameters of Barents Sea harp seals, Phoca groenlandica. ICES J. Mar. Sci., 52: 197-208.

LOENG, H. 1989. The influence of temperature on some fish population parameters in the Barents Sea. J. Northwest Atl. Fish. Sci., 9: 103-113.

LOVE, R. M. 1970. The chemical biology of fishes. Academic Press. London.

MCCRACKEN, F. D. 1958. On the biology and fishery of the Canadian Atlantic halibut, Hippoglossus hippoglossus L. J. Fish. Res. Board. Can., 15: 1269-1311.

MEHL, S. and SUNNANÅ, K. 1991. Changes in growth of Northeast Arctic cod in relation to food consumption in 1984-1988. ICES Mar. Sci. Symp., 
193: $109-112$.

MØLLER, D. 1968. Genetic deversity in cod. Hereditas, 60: $1-32$.

MØLLER, D. 1969. The relationship between Arctic cod and coastal cod in their immature stages illustrated by frequencies of genetic characters. Fiskridir. Skr. Havunders., 15: 220-223.

MORK, J., N. RYMAN, G. STÅHL, F, UTTER, and G. SUNDNES. 1985. Genetic variation in Atlantic cod (Gadus morhua L.) throughout its range. Can. J. Fish. Aquat. Sci., 42: 1580-1587.

MORK, J. 1985. Biochemical genetic studies in fish. A summary of results from some recent studies in fisheries biology. Dr. Philos. Thesis, University of Trondheim, Trondheim.

NAKKEN, O., and A. RAKNES. 1987. The distribution and growth of northeast Arctic cod in relation to bottom temperatures in the Barents Sea, 1978-1984. Fish. Res., 5: 243-252.

PEDERSEN, T. 1984. Variation of peak spawning of Arcto-Norwegian cod (Gadus morhua L.) during the time period 1929-1982 based on indices estimated from fishery statistics. Floedevigen Rapp., 1: 301-
316.

RAE, B. B. 1959. Halibut observations on its size at first maturity, sex ratio and length/weight relationships. Mar.Res., Scot., 4: 1-19.

ROFF, D. A. 1982. Reproductive strategies in flatfish: a first synthesis. Can. J. Fish. Aquat. Sci., 39: 16861698.

ROLLEFSEN, G. 1933. The Otoliths of the Cod. Fiskeridir. Skr. Havunders, 4(3): 1-18.

STEARNS, S. C., and R. E. CRANDALL. 1984. Plasticity for age and size at sexual maturity: a life-history response to unfavourable stress. In: Fish Reproduction, G. W. Potts and R. J. Wootton (eds). Academic Press, London, p. 13-33.

SÆTERSDAL, G., and A. HYLEN. 1964. The Decline of the Skrei Fisheries. (A review of the landing statistics 1866-1957 and an evalutation of the effects of the postwar increase in the total exploitation of the Arctic cod.). Fiskridir. Skr. Havunders., 13(7): 56-69.

TILSETH, S. 1993. Cold water round-fish species for aquaculture in the North Atlantic. Spec. Publ. Eur. Aquacult. Soc., 19: 294 p. 
